\title{
TRACKING ARAH PANDANGAN MATA UNTUK PENILAIAN DESAIN POSTER BERDASARKAN SALIENSI
}

\author{
Agus Wibowo ${ }^{1}$, Lukman Zaman ${ }^{2}$ \\ ${ }^{1,2}$ Sekolah Tinggi Teknologi Surabaya, Jl. Ngagel Jaya Tengah, Jawa Timur, Indonesia \\ ${ }^{1}$ agusaknela@gmail.com \\ ${ }^{2}$ luqmanzestts.edu
}

\begin{abstract}
In the eye-gaze detection, a person's focus and attention is captured through their eye gaze movements. In its implementation, eye-gaze tracking can be used to determine whether a poster design is consistent or not. If it is consistent, the poster is considered good according to poster design experts. This can provide benefits to creative industry players in assessing whether the posters made are in accordance with what is expected in terms of design. Glance detection is applied by taking part of the face image per video frame, then taking the eye part, and finally detecting the center point of the pupil image from the eye. The point where the pixel center of the pupil is recorded is to look for data on 9 areas of the poster that are often glanced by the eye. Then the glance data and the saliency score will be obtained. These two data are compared with the poster data in which the important areas have been marked by the poster design specialist. Therefore, the information about the consistency of the poster design will be obtained as well. This study has produced an $74 \%$ accuracy in analyzing the consistency of poster designs based on eye detection.
\end{abstract}

Keywords - Eye Gaze, Poster, Saliency, Viola Jones

Intisari-Dalam eye-gaze detection, fokus dan perhatian seseorang ditangkap melalui tatapan dan gerakan matanya. Dalam implementasinya eye-gaze tracking dapat digunakan untuk untuk mengetahui konsisten atau tidaknya sebuah desain poster. Jika konsisten maka poster dianggap sudah baik menurut pakar desain poster. Hal ini dapat memberikan manfaat kepada pelaku industri kreatif untuk menilai poster yang dibuat apakah sudah sesuai dengan apa yang diharapkan dari segi desain. Deteksi lirikan mata dilakukan dengan mengambil bagian citra wajah per frame video, lalu diambil bagian mata, dan terakhir mendeteksi titik pusat citra pupil dari mata. Titik lokasi piksel pusat pupil dicatat untuk mencari data 9 area poster yang sering dilirik oleh mata. Kemudian akan diperoleh data lirikan dan skor saliency. Kedua data ini dibandingkan dengan data poster yang telah ditandai area yang penting oleh pakar desain poster. Lalu akan didapatkan informasi mengenai konsistensi desain poster. Penelitian ini menghasilkan akurasi sebesar $\mathbf{7 4 \%}$ dalam menganalisa konsistensi desain poster berdasarkan deteksi lirikan mata.

Kata Kunci_Eye Gaze, Poster, Saliensi, Viola Jones

\section{PENDAhuluan}

Dewasa ini berbagai teknik eye-gaze detection mendapatkan banyak perhatian dari para peneliti di seluruh dunia, hal ini dikarenakan teknik ini dapat digunakan dan dikembangkan untuk berbagai hal seperti
Human Machine Interface, Robotika, Studi Psychological, Sistem Kontrol dan Keamanan, dan lain-lain.

Dalam eye-gaze detection, fokus dan perhatian seseorang ditangkap melalui tatapannya dan gerakan matanya. Seiring dengan berkembangnya teknologi, para peneliti melakukan banyak penelitian untuk membuat sebuah sistem yang interaktif dan intuitif, fokus dan perhatian dari objek tidak hanya dilihat dari tatapannya, namun dilihat juga dari Fitur Tatapan Lokal (sudut mata, pupil, batas mata bagian dalam, posisi refleksi kornea, dan iris. Hal ini lah yang kemudian menjadi titik awal untuk melihat pelacakan lokalisasi iris.

Secara umum metode eye-gaze tracking dibagi menjadi dua tipe pendekatan, yaitu metode yang menggunakan pendeteksian feature dan metode berbasis model. Metode pertama dapat mengenali mata dengan cepat dan mudah namun membutuhkan gambar dengan kualitas yang tinggi, sedangkan metode yang kedua menggunakan model tertentu dalam pendeteksian gambar seperti neural network, algoritma genetika, dll. Metode ini membutuhkan waktu yang lebih lama dalam melakukan pendeteksian namun hasil yang didapat lebih akurat.

Dalam dunia desain banyak desainer pemula yang belum memahami arsitektur desain khususnya poster yang baik dan bisa berhasil menyampaikan tujuan dari informasi yang disampaikan kepada pembaca. Pembaca mungkin tidak membaca sebuah poster secara keseluruhan, hanya bagian-bagian tertentu yang dirasa menarik yang akan dilihat dan dibaca. Sebagai contoh Poster promosi produk UMKM/Industri Kreatif, apakah poster yang dibuat sudah bisa menyampaikan informasi kepada pembaca, jika belum bisa atau kurang dalam menyampaikan informasi maka bisa dengan cepat merevisi poster yang dibuat sehingga akan lebih cepat dalam mempromosikan produknya.

Berdasarkan permasalahan yang telah dijelaskan, penulis mengusulkan untuk melakukan penelitian mengenai Tracking Arah Pandangan Mata untuk Penilaian Desain Poster Berdasarkan Saliensi. Setelah mata dideteksi dari potongan video webcam selanjutnya akan diperoleh area mana saja yang lebih sering dilihat oleh mata berdasar 9 area titik dan kemudian dihitung nilai saliensinya. Hasil tersebut akan dibandingkan dengan poster yang sudah ditandai oleh pakar desain poster apakah sudah konsisten atau belum. Jika konsisten maka poster berarti sudah bagus menurut pakar desain poster. Jika belum konsisten maka poster dianggap belum 
bisa menyampaikan informasi kepada pembaca sehingga harus diperbaiki.

\section{LANDASAN TEORI}

Ibrahim, Farah Nadia, dkk (2018) [6] memperkenalkan deteksi titik tengah mata dengan cara mengkombinasikan algoritma Viola-Jones dengan Neural Network Algrithms. Inti pada penelitian ini adalah untuk memperbaiki akurasi deteksi pupil dengan proses 5 dan 9 poin kalibrasi untuk mengambil koordinat-koordinat titik tengah pupil seperti pada Gambar 1.
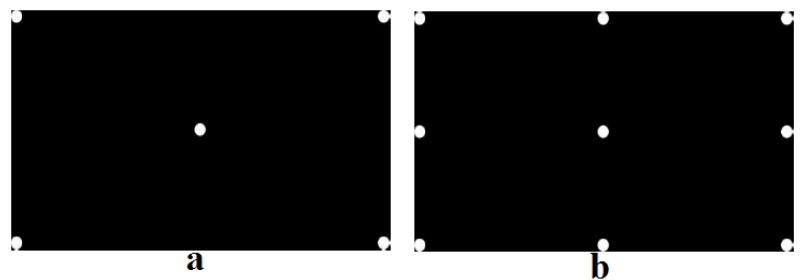

Gambar 1. Kalibrasi (a) Titik 5 (b) Titik 9

Koordinat diperoleh menggunakan algoritma ViolaJones. Data koordinat yang didapat akan dijadikan dataset eye gaze untuk keperluan pelatihan data pada Neural Networks. Dataset berupa video yang direkam menggunakan webcam Logitech HD Pro Webcam C920 dengan spesifikasi full 1080p HD. Dataset diperoleh dari tiga partisipan. Proses pengambilan data dilakukan 6 kali pada setiap tiga partisipan dengan dua macam kalibrasi.

Shiwei Chenga, dkk (2015) [4] melakukan pendekatan untuk mendeteksi tatapan mata pada suatu gambar menggunakan webcam. Tujuan utamanya adalah untuk menganalisa visual attention atau perhatian visual yang dihasilkan oleh tatapan/lirikan mata. Dataset berupa citra yang akan ditatap oleh mata para responde. Tatapan mata responden akan direkam untuk mengetahui bagian citra mana saja yang ditatap mata responden. Proses ini terdiri dari 4 bahan yaitu perintah yang ditujukakn kepada responden, kemudian ada citra mask untuk memotong citra uji, dan ada citra grid seukuran citra uji untuk mengetahui garis-garis yang mengenai citra. Setelah mendapatkan citra saliency dari eye gaze, maka akan dijadikan biner untuk memotong citra uji. Sehingga output akhir adalah berupa titik-titik citra yang dominan ditatap mata oleh responden.

Abhilash dan Dharun (2017) [7] menawarkan metode untuk menemukan segmen dan centroid citra pupil untuk identiifikasi iris. Kemudian proses deteksi tepi dengan metode image canny dengan bantuan metode connected components. Komponen-komponen yang didapat kemudian dicari nilai centroid pada setiap pupil yang dideteksi dan akan dijadikan vektor fitur data iris. Metode Canny Edge Detection terdiri dari tahap smoothing, menemukan gradien, non-maximum suppression, double thresholding untuk hapus noise, dan hysteresis based edge tracking. Kemudian dilakukan proses thresholding untuk mengubah citra keabu-abuan menjadi biner. Kemudian dilakukan labeling menggunakan teknik connected component berupa fungsi "bwconncomp" pada Matlab. Lalu dilanjutkan mendeteksi centroid menggunakan fungsi "regionprops" pada Matlab.

\section{METODE PENELITIAN}

Pada penelitian ini akan dijelaskan beberapa tahapan sistem yang diusulkan yaitu penjelasan tentang akuisisi data dan gambaran sistem.

\section{A. Akuisisi Data}

Data didapat dari video yang diambil dari webcam yang terpasang di monitor atau webcam yang berada di laptop dengan aplikasi bawaan webcam. Perekaman video di ambil dengan durasi pendek maksimal 5 detik pada saat mata memandang desain poster yang ditampilkan di layar monitor dengan jarak $30 \mathrm{~cm}$. Poster yang digunakan menggunakan orientation portrait atau Landscape dengan resolusi minimal $150 \mathrm{pixel} / \mathrm{inch}$. Pengambilan video dengan webcam harus memperhatikan cahaya agar wajah dan pupil bisa terlihat jelas. Jika pengambilan video di dalam ruangan maka menggunakan bantuan cahaya yang disorotkan ke wajah. Jika pengambilan video di luar ruangan hendaknya memperhatikan arah datangnya cahaya matahari.

\section{B. Gambaran Sistem}

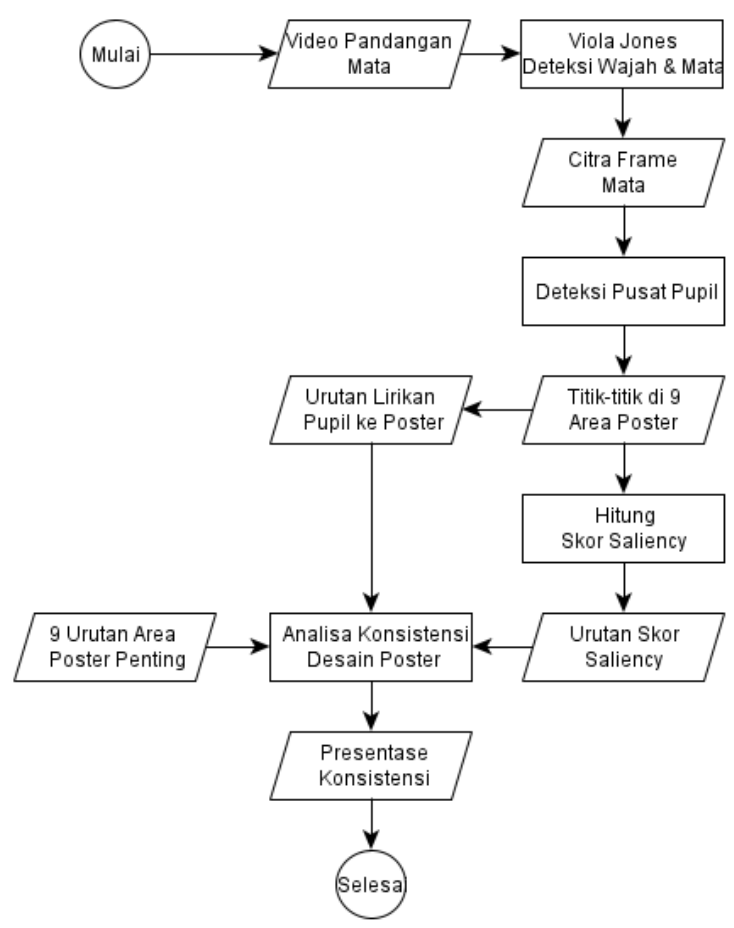

Gambar 2. Sistem yang diusulkan

\section{Deteksi Wajah dan Mata}

Setiap citra frame dari video akan melalui proses deteksi wajah dan mata menggunakan algoritma Viola Jones. Citra frame tidak terbatas pada ukuran, bisa potrait atau landscape. Desain sistem deteksi mata secara keseluruhan di bedakan menjadi beberapa tahap mulai dari input berupa visual gambar wajah yang di ambil secara terus menerus menggunakan kamera ponsel lalu diproses dengan pendeteksian objek mata. Proses pendeteksian objek mata dibagi 2 tahap yaitu visual wajah menjadi pendeteksian wajah, dan deteksi wajah menjadi deteksi mata. Desain sistem deteksi wajah seperti pada Gambar 3. 


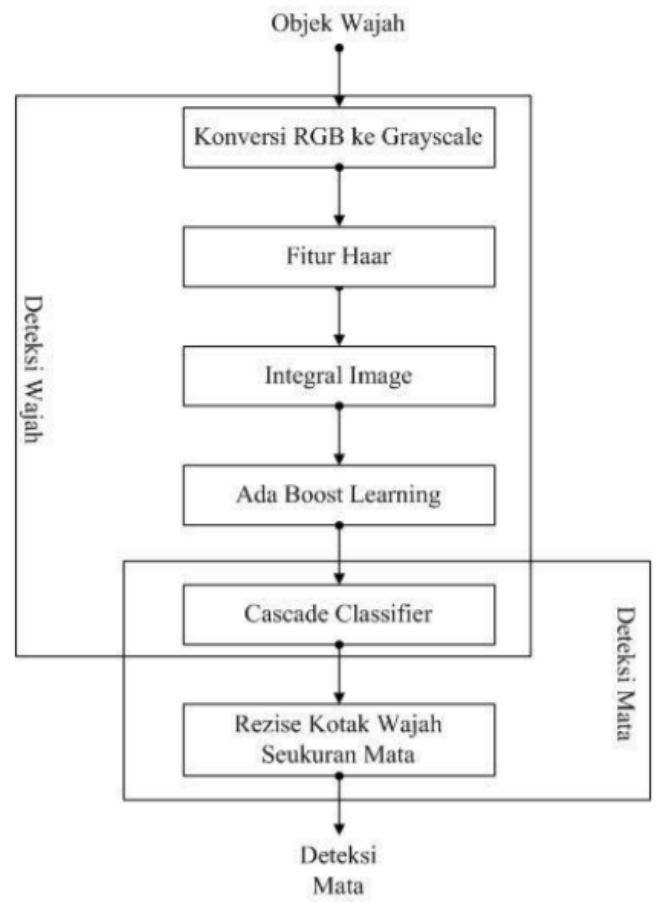

Gambar 3. Alur Deteksi Mata

2. Deteksi Pusat Pupil

Deteksi gerakan pupil mata menggunakan fungsi regionprops pada matlab untuk mencari obyek lingkar. Kemudian obyek lingkar tersebut akan dicari titik pusatnya dengan cara lebar \& tinggi citra dibagi 2.

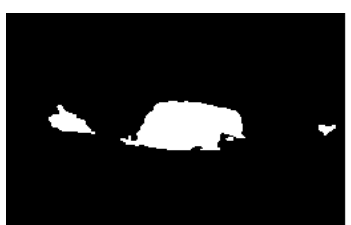

(a)

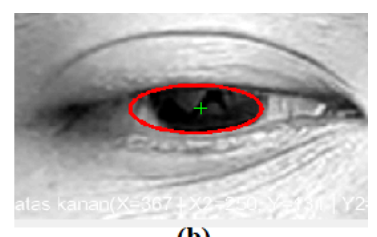

(b)
Gambar 4. Deteksi Pusat Pupil (a) Regionprops, (b) Pusat Pupil

Setiap pupil bergerak, maka nilai tengah (centroid) dari pupil memiliki alamat area (x, y) yang berbeda. Alamat nilai tengah ini yang digunakan untuk menentukan apakah nilai tengah dari pupil berada di salah satua dari 9 area.

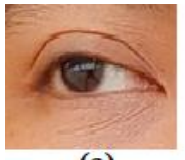

(a)

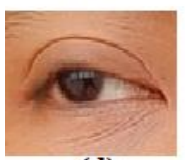

(d)

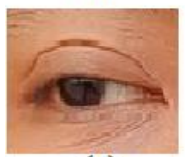

(g)

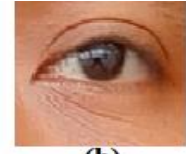

(b)

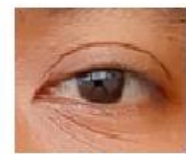

(e)

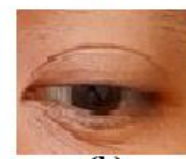

(h)

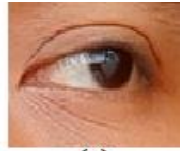

(c)

(f)

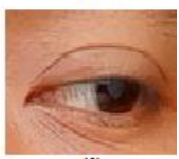

(i)

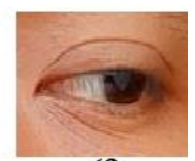

Gambar 5. Lirikan Pupil 9 Area
Citra mata akan diubah ukuranya menjadi 500x500 piksel. Kemudian nilai tengah dari fungsi centriod akan dicatat ke dalam matriks sebagai piksel dengan nilai 1 . Sehingga akan dihasilkan titik-titik hasil gerakan pupil dengan ukuran 500x500 piksel.

Setelah mendapatkan area mata, langkah selanjutnya adalah pendeteksian pergerakan mata menggunakan 9 titik area yaitu atas_kiri, atas_kanan, bawah_kiri, bawah_kanan, atas_tengah, bawah_tengah, kanan_tengah, kiri_tengah, tengah. Selanjutnya digambarkan berupa titik pergerakan mata. Kemudian pada garis eye gaze diberi nomor urut setiap lirikan mata untuk mengetahui daerah mana yang pertama kali hingga terakhir kali dilihat oleh responden. Objek poster yang pertama kali dipandang menandakan bahwa objek tersebut adalah objek yang paling mencolok dan hasil saliency map pada citra poster merupakan area yang paling putih. Contoh hasil titik-titik pandangan mata adalah seperti berikut:
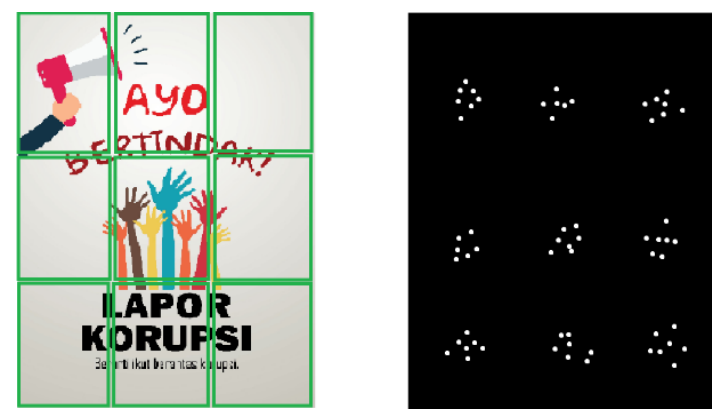

Gambar 6. Garis Eye Gaze

3. Skor Saliency

Citra titik hasil eye gaze yang berupa titik piksel bernilai 1 (putih) akan melalui proses perhitungan saliency. Sehingga akan menghasil citra dengan nilai saliency seperti pada Gambar 6. Keluaran dari sistem adalah skor saliency dikali dengan jumlah lirikan pupil kepada area poster. Contoh perhitungan skor adalah seperti pada Gambar 7.

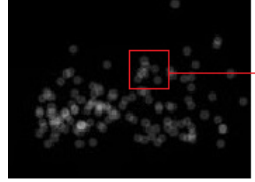

(a)

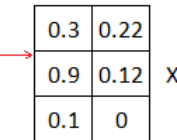

(b)

\begin{tabular}{|l|l|}
\hline 3 & 3 \\
\hline 3 & 3 \\
\hline 3 & 3 \\
\hline
\end{tabular}

(c) \begin{tabular}{|c|c|}
\hline 0,0063 & 0,0458 \\
\hline 0,0188 & 0,025 \\
\hline 0,0021 & 0 \\
\hline
\end{tabular}

(d)
Gambar 7. Contoh Perhitungan Skor (a) Citra Saliency Lirikan (b) Piksel Saliency (c) Jumlah Lirikan Pupil ke Area Tersebut (d) Skor

Semua video akan mendapatkan skor tersebut. Lalu diambil rata-rata setiap 9 area. Skor saliency 9 area ini akan diurutkan dari skor bernilai paling besar hingga paling kecil. Selain itu juga dibandingkan urutan lirikan dari salah satu dari 9 area yang paling pertama hingga paling terakhir.

\section{Konsistensi Desain Poster}

Setelah mendapatkan urutan skor salieny dan urutan lirikan mata terhadap 9 area poster. Maka akan dibandingkan antara skor saliency dari para responden pada setiap poster. Cara membandingkan skor saliency antar responden adalah seperti pada Gambar 8. 


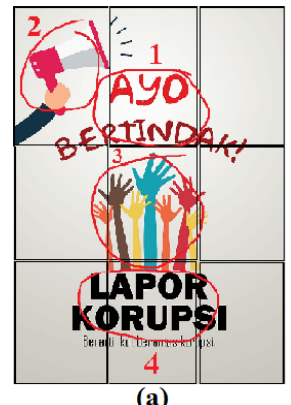

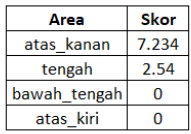

(b)

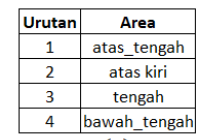

(c)
Gambar 8. Analisa Konsistensi Desain Poster: (a) Penandaan Area Poster Oleh Pakar, (b) Urutan Skor Besar-Kecil, (c) Urutan Lirikan Pertama-Terakhir

Teknik untuk membandingkan hasil uji coba dengan tanda yang diberikan oleh pakar desain poster adalah dengan cara mengambil modus (kejadian terbanyak). Jika hasil modus sama dengan area yang ditandai oleh pakar desain poster, maka desain poster dianggap konsisten.

\section{HASIL DAN PEMBAHASAN}

Data didapat dari beberapa video yang merekam responden saat melihat poster.

Tabel I

Akuisi Data Video Lirikan Pupil

\begin{tabular}{|c|c|}
\hline $\begin{array}{c}\text { Poster } \\
\text { Ke }\end{array}$ & $\begin{array}{c}\text { Jumlah } \\
\text { Responden }\end{array}$ \\
\hline 1 & 5 \\
\hline 2 & 5 \\
\hline 3 & 5 \\
\hline 4 & 5 \\
\hline 5 & 5 \\
\hline 6 & 5 \\
\hline 7 & 5 \\
\hline 8 & 5 \\
\hline$\cdots$ & $\cdots$ \\
\hline 50 & 5 \\
\hline
\end{tabular}

Setiap responden diminta untuk melihat poster dengan durasi waktu maksimal 5 detik. Jumlah poster yang digunakan adalah 50. Setiap poster dilihat oleh 5 responden. Sehingga total video yang akan dipakai dalam penetlian ini adalah 250. Video lirikan pupil setiap responden dapat berbeda dalam satu poster.

Pada uji coba deteksi wajah menggunakan algoritma Viola Jones tidak ada kendala sama sekali. Uji coba deteksi wajah menggunakan algoritma Viola Jones pada video seperti pada Gambar 9. Kemudian setelah diperoleh citra wajah dari video menggunakan algoritma Viola Jones, maka proses selanjutnya adalah uji coba deteksi mata menggunakan algoritma Viola Jones dengan model EyePairBig.

Setelah mendapatkan citra mata, maka proses selanjutnya adalah uji coba deteksi pupil menggunakan algoritma RegionProps (Matlab). Uji coba deteksi pupil dengan algoritma RegionProps seperti pada Gambar 10.

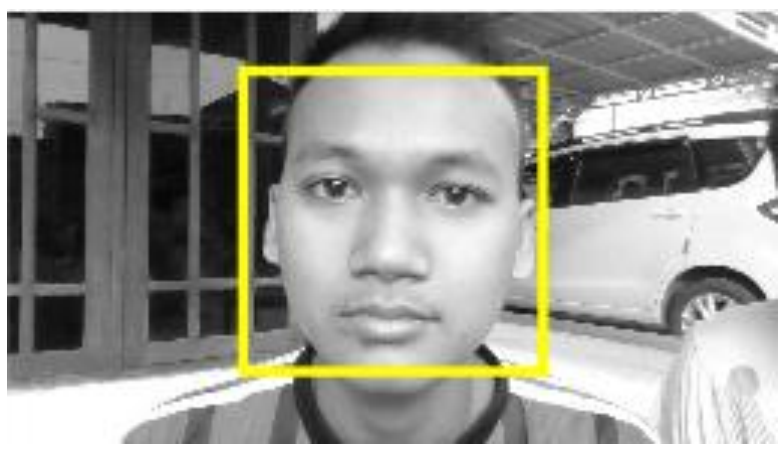

Gambar 9. Uji Coba Deteksi Wajah

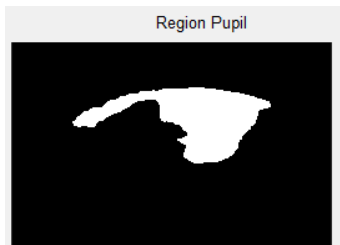

(a)

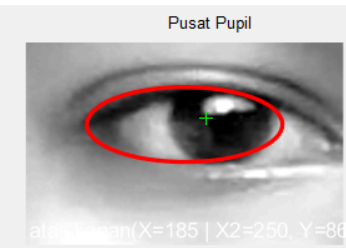

(b)
Gambar 10. Uji Coba Deteksi Pupil(a) Deteksi RegionProps; (b) Plot Citra Pupil

Kendala pada uji coba deteksi pupil adalah jika pada citra mata terdapat warna yang gelap mendekati warna hitam pada bagian pupil. Solusi untuk kendala ini adalah dengan mencerahkan wajah responden menggunakan cahaya tambahan atau di luar ruang dengan sinar matahari. Cahaya matahari sangat membantu memberikan efek cerah pada area wajah yang melengkung agar tidak terlihat hitam menyerupai warna hitam pada pupil.

Pada satu video akan menghasilkan titik-titik putih (piksel "1") sesuai dengan area titik tengah pupil saat melirik desain poster. Pada algoritma yang penulis buat, terdapat perulangan yang dapat menyimpan setiap jenis area (dari 9 area) pada setiap frame video. Pada setiap frame video akan dicatat ambil 1 jenis area titik daria 9 area yang tersedia.

Uji coba deteksi lirikan pupil dilakukan pada 50 poster dengan 5 responden yang berbeda. Setiap video terdapat 9 titik area yang diambil data jumlah lirikan pupilnya. Hasil deteksi lirikan pupil pada poster ke 1 seperti pada Tabel II.

Tabel II

Hasil Deteksi Lirikan Pupil Poster 1

\begin{tabular}{|l|l|l|l|l|l|}
\hline Responden & $\mathbf{1}$ & $\mathbf{2}$ & $\mathbf{3}$ & $\mathbf{4}$ & $\mathbf{5}$ \\
\hline atas_kiri & 9 & 0 & 24 & 0 & 0 \\
\hline atas_kanan & 85 & 187 & 99 & 173 & 30 \\
\hline bawah_kiri & 0 & 0 & 0 & 0 & 0 \\
\hline bawah_kanan & 0 & 0 & 0 & 0 & 5 \\
\hline atas_tengah & 0 & 0 & 0 & 0 & 0 \\
\hline bawah_tengah & 65 & 1 & 9 & 0 & 0 \\
\hline kanan_tengah & 0 & 0 & 0 & 2 & 59 \\
\hline kiri_tengah & 0 & 0 & 0 & 0 & 0 \\
\hline Tengah & 0 & 0 & 0 & 0 & 0 \\
\hline
\end{tabular}


Selama proses deteksi 9 lirikan, telah dicatat jenis area titik yang dilirik. Jika lirikan citra pupil responden berpindah ke area lain maka algoritma akan menyimpanya. Semua data jenis lirikan akan disimpan dan diolah hingga didapatkan jenis area secara unik dan urut. Sehingga dapat diketahui jenis area yang dilirik pertama, kedua, hingga kesembilan. Hasil pencatatan urutan lirikan pupil seperti pada Tabel III.

Tabel III

Hasil Urutan Lirikan Area Pupil Poster 1

\begin{tabular}{|c|c|c|c|c|c|c|}
\hline \multirow{2}{*}{ Urut } & \multicolumn{5}{|c|}{ Responden } & \multirow{5}{*}{ 芯 } \\
\hline & 1 & 2 & 3 & 4 & 5 & \\
\hline 1 & $\begin{array}{l}\text { atas } \\
\text { kanan }\end{array}$ & $\begin{array}{l}\text { atas } \\
\text { kanan }\end{array}$ & $\begin{array}{l}\text { atas } \\
\text { kanan }\end{array}$ & $\begin{array}{l}\text { atas } \\
\text { kanan }\end{array}$ & $\begin{array}{l}\text { atas } \\
\text { kanan }\end{array}$ & \\
\hline 2 & $\begin{array}{l}\text { atas } \\
\text { kiri }\end{array}$ & $\begin{array}{l}\text { bawah } \\
\text { tengah }\end{array}$ & $\begin{array}{l}\text { atas } \\
\text { kiri }\end{array}$ & $\begin{array}{l}\text { Kanan } \\
\text { tengah }\end{array}$ & $\begin{array}{l}\text { Bawah } \\
\text { kanan }\end{array}$ & \\
\hline 3 & & & $\begin{array}{l}\text { bawah } \\
\text { tengah }\end{array}$ & & $\begin{array}{l}\text { Kanan } \\
\text { tengah }\end{array}$ & \\
\hline Teratas & $\begin{array}{c}\text { atas } \\
\text { kanan }\end{array}$ & $\begin{array}{l}\text { atas } \\
\text { kanan }\end{array}$ & $\begin{array}{l}\text { atas } \\
\text { kanan }\end{array}$ & $\begin{array}{l}\text { atas } \\
\text { kanan }\end{array}$ & $\begin{array}{l}\text { atas } \\
\text { kanan }\end{array}$ & $\begin{array}{c}\text { atas } \\
\text { kanan }\end{array}$ \\
\hline
\end{tabular}

Setelah mendapatkan data jumlah 9 titik lirikan pupil, maka proses selanjutnya adalah menghitung skor saliency. Skor saliency bisa digunakan untuk mencari urutan area dari 9 titik yang dianggap paling sering/lama dilirik hingga titik yang dianggap kurang/jarang dilirik. Hasil uji coba perhitungan skor saliency beserta urutanya seperti pada Tabel IV.

Tabel IV

Hasil Skor Saliency Poster 1

\begin{tabular}{|c|c|c|c|c|c|c|}
\hline Responden & 1 & 2 & 3 & 4 & 5 & \multirow{10}{*}{ 亯 } \\
\hline atas_kiri & $\begin{array}{c}0.83 \\
303\end{array}$ & 0 & 10.7527 & 0 & 0 & \\
\hline atas_kanan & $\begin{array}{l}26.7 \\
158 \\
\end{array}$ & $\begin{array}{l}76.9 \\
773 \\
\end{array}$ & 35.8207 & 69.7646 & 35 & \\
\hline bawah_kiri & 0 & 0 & 0 & 0 & 0 & \\
\hline bawah_kanan & 0 & 0 & 0 & 0 & $\begin{array}{c}6.00 \\
02 \\
\end{array}$ & \\
\hline atas_tengah & 0 & 0 & 0 & 0 & 0 & \\
\hline bawah_tengah & $\begin{array}{l}19.3 \\
903 \\
\end{array}$ & $\begin{array}{c}0.00 \\
1\end{array}$ & $\begin{array}{c}9.0909 \mathrm{e} \\
-05\end{array}$ & 0.13932 & 51 & \\
\hline kanan_tengah & 0 & 0 & 0 & 0 & 0 & \\
\hline kiri_tengah & 0 & 0 & 0 & 0 & 0 & \\
\hline Tengah & 0 & 0 & 0 & 0 & 0 & \\
\hline MAX & $\begin{array}{c}\text { atas } \\
\text { _ka } \\
\text { nan }\end{array}$ & $\begin{array}{c}\text { atas } \\
\text { _ka } \\
\text { nan }\end{array}$ & $\begin{array}{c}\text { atas_ka } \\
\text { nan }\end{array}$ & $\begin{array}{c}\text { atas_ka } \\
\text { nan }\end{array}$ & $\begin{array}{c}\text { atas } \\
\text { _ka } \\
\text { nan }\end{array}$ & $\begin{array}{c}\text { atas_ka } \\
\text { nan }\end{array}$ \\
\hline
\end{tabular}

Setelah didapatkan hasil urutan area poster yang dilirik terbanyak hingga terkecil dan data skor saliency, maka uji coba selanjutnya adalah membandingkan kedua hasil uji coba terbsebut dengan desain poster yang telah ditandai oleh pakar desain poster. Contoh desain poster yang telah ditandai areanya oleh pakar desain poster seperti pada Gambar 11. Pada Gambar 11 telah terdapat beberapa lingkaran warna kuning. Lingkaran ini bertujuan untuk memberi tanda area poster yang menurut pakar desain poster adalah bagian poster yang menarik perhatian dan disertai urutannya.

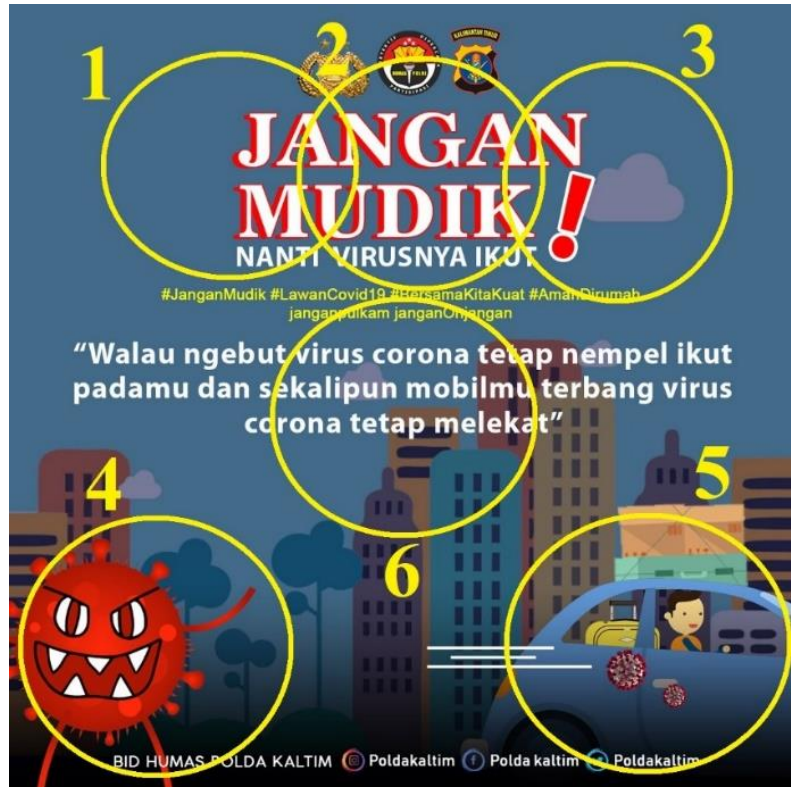

Gambar 11. Area Poster Ditandai oleh Pakar Desain Poster

Teknik untuk membandingkan hasil uji coba dengan tanda yang diberikan oleh pakar desain poster adalah dengan cara mengambil modus (kejadian terbanyak). Jika hasil modus sama dengan area yang ditandai oleh pakar desain poster, maka desain poster dianggap konsisten. Perbandingan antara nilai hasil uji coba dengan nilai dari pakar desain poster seperti pada Tabel V.

Tabel V

Uji Coba Konsistensi Poster

\begin{tabular}{|c|c|c|c|c|}
\hline $\begin{array}{c}\text { No } \\
\text { Area }\end{array}$ & $\begin{array}{c}\text { Modus } \\
\text { Urutan } \\
\text { Jumlah } \\
\text { Lirikan }\end{array}$ & $\begin{array}{c}\text { Modus } \\
\text { Urutan } \\
\text { Skor } \\
\text { Saliency }\end{array}$ & $\begin{array}{c}\text { Urutan } \\
\text { dari Pakar }\end{array}$ & Konsistensi \\
\hline 1 & atas_kanan & atas_kanan & atas_kanan & YA \\
\hline 2 & & & atas_tengah & - \\
\hline 3 & & & atas_kiri & - \\
\hline 4 & & & bawah_kanan & - \\
\hline 5 & & & Bawah_kiri & - \\
\hline 6 & & & Tengah & - \\
\hline 7 & & & & YA \\
\hline
\end{tabular}

Dari Tabel V telah diketahui bahwa desain poster termasuk konsisten, karena hasil dari modus konsistensi adalah "YA". Jika salah satu Modus Urutan ada yang sama dengan urutan dari poster maka dianggap konsisten Setelah diketahui modus konsistensi dari setiap satu desain poster, maka akan dilakukan presentase untuk seluruh hasil uji coba dari semua desain poster. Presentase ini akan menjadi akurasi pada penelitian ini. Untuk mendapatkan presentasi keberhasilan penelitian ini, dibutuhkan proses pengujian untuk 50 poster dengan masing-masing poster dilihat oleh 5 responden. Contoh hasil uji coba semua video seperti pada Tabel VI. 
Tabel VI

Uji Coba Konsistensi Poster 50 Poster

\begin{tabular}{|c|c|c|c|c|c|}
\hline $\begin{array}{c}\text { POS } \\
\text { TER } \\
\text { KE }\end{array}$ & $\begin{array}{c}\text { KONSI } \\
\text { STEN }\end{array}$ & $\begin{array}{l}\text { POS } \\
\text { TER } \\
\text { KE }\end{array}$ & $\begin{array}{c}\text { KONSIS } \\
\text { TEN }\end{array}$ & $\begin{array}{l}\text { POS } \\
\text { TER } \\
\text { KE }\end{array}$ & $\begin{array}{c}\text { KONSI } \\
\text { STEN }\end{array}$ \\
\hline 1 & YA & 18 & TIDAK & 35 & YA \\
\hline 2 & YA & 19 & TIDAK & 36 & YA \\
\hline 3 & YA & 20 & YA & 37 & YA \\
\hline 4 & YA & 21 & YA & 38 & TIDAK \\
\hline 5 & YA & 22 & YA & 39 & YA \\
\hline 6 & YA & 23 & YA & 40 & YA \\
\hline 7 & YA & 24 & YA & 41 & TIDAK \\
\hline 8 & YA & 25 & YA & 42 & TIDAK \\
\hline 9 & YA & 26 & TIDAK & 43 & YA \\
\hline 10 & TIDAK & 27 & YA & 44 & YA \\
\hline 11 & YA & 28 & YA & 45 & YA \\
\hline 12 & TIDAK & 29 & TIDAK & 46 & YA \\
\hline 13 & TIDAK & 30 & YA & 47 & YA \\
\hline 14 & TIDAK & 31 & TIDAK & 48 & YA \\
\hline 15 & YA & 32 & YA & 49 & YA \\
\hline 16 & YA & 33 & TIDAK & 50 & YA \\
\hline 17 & YA & 34 & YA & & \\
\hline \multicolumn{6}{|c|}{ TOTAL KONSISTEN } \\
\hline \multicolumn{3}{|c|}{$\sum \mathbf{Y A}=37$} & \multicolumn{3}{|c|}{$\sum$ TIDAK $=13$} \\
\hline \multicolumn{6}{|c|}{$\begin{array}{c}\text { AKURASI }= \\
\frac{37}{50} \times 100=749\end{array}$} \\
\hline
\end{tabular}

Berdasarkan Tabel VI hasil akurasi dari penelitian ini adalah $74 \%$. Poster dengan jumlah objek yang sangat banyak bisa membuat responden melirik area yang sangat beragam. Menurut analisa yang dilakukan, poster dengan objek yang banyak dapat menurunkan konsistensi desain poster.

Hasil output sistem adalah jumlah lirikan, urutan lirikan, dan skor saliency. Data jumlah lirikan digunakan untuk keperluan perhitungan skor saliency. Kemudian data urutan lirikan dan data skor saliency digunakan untuk keperluan analisa konsistensi desain poster. Proses konsistensi desain poster dilakukan dengan membandingkan data urutan lirikan dan urutan skor saliency dari yang terbesar hingga yang terkecil dengan area poster yang telah ditandai oleh pakar. Pengujian ini dilakukan pada setiap 50 poster, dan setiap poster terdapat 5 video yang dihasilkan rekaman dari 5 responden.

\section{KESIMPULAN}

Berdasarkan uraian penjelasan di atas, maka dapat diambil kesimpulan bahwa dari 50 poster yang dilihat oleh 250 video responden memiliki hasil akurasi konsistensi $74 \%$. Sehingga bisa dikatakan bahwa contoh poster yang dipakai dalam penelitian sudah baik dan berhasil dalam menyampaikan informasi kepada pembaca. Hal ini bisa dilihat dari konsistensi antara hasil lirikan mata responden dengan poster yang sudah ditandai oleh pakar desain poster.

\section{UCAPAN TERIMA KASIH}

Ucapan terimakasih kepada ISTTS dan semua teman/ sahabat yang telah membantu baik tenaga maupun pikiran demi terlaksananya penelitian ini.

\section{REFERENSI}

[1] N. H. Cuong and H. T. Hoang, "Eye-gaze detection with a single WebCAM based on geometry features extraction," 2010 11th International Conference on Control Automation Robotics \& Vision, 2010.

[2] T.-H. Huynh, "A new eye gaze detection algorithm using PCA features and recurrent neural networks," 2013 IEEE Symposium on Computational Intelligence in Control and Automation (CICA), 2013.

[3] Z. Orman, A. Battal, and E. Kemer, "A Study On Face, Eye Detection And Gaze Estimation," International Journal of Computer Science \& Engineering Survey, vol. 2, no. 3, pp. 29-46, 2011.

[4] S. Sheela and P. Abhinand, "Iris detection for gaze tracking using video frames," 2015 IEEE International Advance Computing Conference (IACC), 2015.

[5] Sorate, P. (2017). Survey Paper on Eye Gaze Tracking Methods and Techniques.

[6] F. N. Ibrahim, Z.M. Zin, and N. Ibrahim, "Eye Center Detection Using Combined Viola-Jones and Neural Network Algorithms," International Symposium on Agent, Multi-Agent Systems and Robotics (ISAMSR), 2018.

[7] A. KS, and V.S. Dharun, "Method to Remove the Noisy Data from Captured Image of Iris and Identifying the Pupil by Detecting Its Centroid," International Journal of Applied Engineering Research, vol. 12, no. 15, pp. 51275130, 2017.

[8] R. Zheng, K. Nakano, H. Ishiko, K. Hagita, M. Kihira, and T. Yokozeki, "Eye-Gaze Tracking Analysis of Driver Behavior While Interacting With Navigation Systems in an Urban Area," IEEE Transactions on Human-Machine Systems, vol. 46, no. 4, pp. 546-556, 2016.

[9] Y. Feng, G. Cheung, W.-T. Tan, P. L. Callet, and Y. Ji, "Low-Cost Eye Gaze Prediction System for Interactive Networked Video Streaming," IEEE Transactions on Multimedia, vol. 15, no. 8, pp. 1865-1879, 2013.

[10] P. Corcoran, F. Nanu, S. Petrescu, and P. Bigioi, "Realtime eye gaze tracking for gaming design and consumer electronics systems," IEEE Transactions on Consumer Electronics, vol. 58, no. 2, pp. 347-355, 2012.

[11] Y.-M. Cheung and Q. Peng, "Eye Gaze Tracking With a Web Camera in a Desktop Environment," IEEE Transactions on Human-Machine Systems, vol. 45, no. 4, pp. 419-430, 2015.

[12] J. Sigut and S.-A. Sidha, "Iris Center Corneal Reflection Method for Gaze Tracking Using Visible Light," IEEE Transactions on Biomedical Engineering, vol. 58, no. 2, pp. 411-419, 2011.

[13] J. Xu, J. Min, and J. Hu, "Real-time eye tracking for the assessment of driver fatigue," Healthcare Technology Letters, vol. 5, no. 2, pp. 54-58, 2018. 